\title{
DE RAADPENSIONARIS MR. LAURENS PIETER VAN DE SPIEGEL EN ZIJN KOLONIALE POLITIEK JEGENS DE WEST
}

\author{
EEN BIJDRAGE TOT DE GESCHIEDENIS VAN WESTINDIË \\ IN HET LAATST DER 18DE EEUW
}

DOOR

\section{A. HALLEMA}

„Van de Spiegel, de Raadpensionaris die de W(est) I(ndische) C(ompagnie) opruimde, had ook ten aanzien der O.I.C. geen illusie meer”. „Ik had gaarne de O.I.C. behandeld als de West", verklaarde hij in 1795 aan Valckenaer, maar ik kreeg zooveel handen op mijn hoofd, dat ik dit moest laten varen. Zoo ik mij desaangaande gedurende mijn ministerie iets reprocheer, is het het gestadig secours in geld; dat lichaam is niet te redden". Intusschen dokterde men er nog lustig mede om."

Prof. H. T. Colenbrander, Koloniale Gesch., II, 297.

Deze uitspraak van een gezaghebbend deskundige op koloniaalhistorisch gebied zou bij simpele lezing doen vermoeden, dat de bekwame Raadpensionaris Van de Spiegel aan de tweede Westindische Compagnie geen anderen dienst heeft bewezen dan haar "op te ruimen" en haar bezittingen in de West en aan de Westkust van Afrika te stellen onder patronaat van de Regeering der Republiek. Dit vermoeden dient echter als een onjuiste veronderstelling te worden gewraakt en bovendien mag op de groote beteekenis van Van de Spiegel's koloniale politiek, ook ten aanzien van de West, wel eens even de aandacht worden gevestigd, daar het hier een min of meer vergeten hoofdstuk in onze koloniale geschiedenis betreft. Een geschikte aanleiding daarvoor vonden wij in het feit, dat het op 19 Januari 1937 twee eeuwen geleden was, dat Laurens Pieter van de Spiegel te Middelburg het eerste levenslicht aanschouwde, in de stad dus, waar een der belangrijkste centra der Westindische belangen voor moederland en koloniën was gevestigd, waar eigenlijk de eerste draden van het groote web, dat in de 17de eeuw Zeeland met Holland en de Westindische Koloniën zou omspannen, zijn gesponnen. 
Als een van Van de Spiegel's vele anonieme biografen weet te vertellen, hoezeer hij zich heeft ingespannen om naast de behartiging der staatkundige en economische belangen van het grondgebied der Republiek in Europa de koloniale belangen der natie, in de eerste plaats dus die der V.O.C. en W.I.C., te bevorderen, deze beide corporaties zoo lang mogelijk staande te houden en zoo goed mogelijk te reorganiseeren, dan past het ons ook voor dit moeilijke en hoogst ondankbare werk zijn nagedachtenis een eeresaluut te brengen en met enkele stukken aan te toonen, welke moeiten en zorgen hij zich tot dien einde heeft getroost. Samenvattend wat die heroieke arbeid voor de natie van toen en later dagen heeft beteekend, werd dit eens aldus weergegeven: „De toestand der financiën in Holland en die der O. en W. Indische Compagnie, welke met een geheelen ondergang werden bedreigd, vorderde Van de Spiegel's grootste inspanning, maar toch slaagde hij er in daarin eenige verbetering te brengen, ook ondanks tegenwerking en verzet. Hij trachtte een aantal misbruiken en gebreken in verschillende takken van bestuur te verhelpen, ook daarbij tegengewerkt door vooroordeel en baatzucht, terwijl de oorlog (1780-'84) hem het bereiken zijner oogmerken onmogelijk maakte. Het beheer der Westindische koloniën liet vooral veel te wenschen over en overtuigd van het groote belang dezer aangelegenheid, rustte hij niet, voordat hij elke tegenkanting had overwonnen en een geheele verandering in dat bestuur had teweeggebracht, waarvan zich de voordeelen niet lang lieten wachten ${ }^{1}$ ). Met al zijn vermogen en kennis van zaken betreffende de regeeringsvormen in eigen land en de omliggende Europeesche Staten, niet minder van de koloniale instellingen en belangen hier en in andere werelddeelen, trachtte hij bij de toenmaals bekende woelingen in Europa den vrede te bewaren en het kan allerminst worden ontkend, dat hij destijds inderdaad er veel toe heeft bijgedragen om de rust is ons werelddeel zooveel en zoolang mogelijk te handhaven. Hoe hij er naderhand voor beloond werd, bewijst zijn gevangenschap in Den Haag en op het Woerdensche kasteel, waar hij als vroegere staatsgevangenen zijn mémoires schreef."

Zoo neemt dus deze geheel eenige figuur haar plaats in binnen het raam der politieke en economische geschiedenis van de West en moge hier in de eerste plaats voor zijn persoon eenige belangstelling worden verwacht, om daarna de vraag te beantwoorden: Wanneer heeft Van de Spiegel het eerst zijn belangstelling getoond voor de belangen van de West.

1) Ik cursiveer, $\mathrm{H}$. 
Laurens Pieter van de Spiegel dan werd, als gezegd, 19 Januari 1737 te Middelburg geboren uit een aanzienlijk geslacht, oorspronkelijk uit Vlaanderen afkomstig maar in vroeger eeuwen tengevolge der godsdienstige beroeringen naar Zeeland geweken. Hij was nog pas veertien jaar oud, toen hij reeds wees werd, doordat zijn vader, kapitein ter zee in dienst der Oostindische Compagnie, stierf in den bloei zijner jaren, al spoedig gevolgd door zijn moeder, die haar veelbelovenden zoon voor den handel had bestemd. Jan Reinier Maartens, kiesheer der stad Middelburg en kassier van de Ver. Oostind. Compagnie en Mr. Johan Willem de Bruyn namen nu de zorg voor de drie ouderlooze kinderen op zich - Laurens Pieter had namelijk twee zusters, Cornelia Hendrina en Johanna Catharina - , welke spoedig uitstekende voogden voor de misdeelde kinderen bleken te zijn. Hoe reeds toen de aanleg voor het financiewezen zich in den knaap openbaarde, blijkt uit de mededeeling van Prof. Vreede, een der oudste biografen van Van de Spiegel. „De noodzakelijkheid” om voor eigen belang te waken, voor dat van geliefde zusters, weezen als hij, plegtig op te treden en het als het zijne te behartigen, oefende hem in de kennis van menschen en zaken en scherpte zijn geest op het cijferen. De ongunst der tijden leerde den toekomstigen financier het verschil tusschen rentegevende en onvruchtbare schuldbrieven, hetzij Staatspapier, of Oost- en Westindische obligatien en uitstaande vorderingen tegen bijzondere personen. Als de oudste van het drietal, had de veertienjarige Laurens Pieter na het overlijden van de betreurde moeder maanden lang het huishouden bestierd en uitgaven gedaan, die hem sedert „per affirmatie" werden terugbetaald".

Aan de Latijnsche school in zijn geboortestad bereidde hij zich voor tot de universitaire studiën, die hij te Leiden reeds op 17jarigen leeftijd aanving, om zich voor het doctoraat in de beide rechten te bekwamen. In 1758 verwierf hij dien graad met veel lof en kwam nu, mede door zijn liefdesbetrekking met de Goesche burgemeestersdochter Digna Johanna Ossewaarde, het eerst in aanmerking voor de vervulling van de vacature op de secretarie te Goes. Bewees hij in die betrekking aan Zeeland en zijn bewoners reeds belangrijke diensten, mede door zijn afvaardiging ter Statenvergadering, dit werd nog van te meer importantie, toen hij in 1780 secretaris der Staten van Zeeland en in 1785 raadpensionaris van dat gewest werd. Ondanks de vele aan die openbare ambten verbonden werkzaamheden, vooral tengevolge van den vierden Engelschen Oorlog en de daarop gevolgde openlijke 
partijschap tusschen de Patriotten en Prinsgezinden, wist Van de Spiegel nog vrijen tijd te vinden voor zijn studiën in de staatsleer en het staatsrecht, de economie en de geschiedenis, het financiewezen en de letteren. De geschriften, die hij reeds in deze jaren het licht deed zien, bewijzen zijn groote kennis en belezenheid in allerlei zeer uiteenloopende onderwerpen van studie en wat meer zegt, met de pen in de hand las en noteerde hij en legde in tal van handschriften vast wat hij wenschte te onthouden of wat hij voor het nageslacht van beteekenis achtte. Aan die loffelijke methode van onderzoek en voortdurende aanteekening van wat hem merkwaardig voorkwam, danken wij zooveel thans nog bewaard gebleven bijzonderheden, ook over koloniale aangelegenheden van zijn tijd. Zelf schreef hij daarover reeds in zijn Goesche periode aan Ds. Te Water (d.d. 19 Juni 1762), dat hij zich tot gewoonte en stelregel had aangenomen, om „nooit te lezen, voornamelijk niets nieuws zonder aan te teekenen (gelijk hij zich elders uitdrukt) hetgeen mij daarin opmerkelijk voorkomt en ook, hetgeen mij voorkomt pro modulo ingenii, dat daarbij zou kunnen gedaan of veranderd worden". Voor onze koloniale geschiedenis is die methode wel zeer vruchtdragend geweest, zooals hierna met eenige details uit zijn notities nader zal worden bewezen.

Reeds gedurende die Zeeuwsche periode pakten echter ook donkere wolken boven zijn hoofd samen, vooral het gevolg van de politieke woelingen en burgertwisten, die in zijn eigen gewest des te gevaarlijker vormen aannamen, doordat de partij, die verandering beoogde van den bestaanden staatkundigen toestand, er zeer machtig was en steeds driester het hoofd opstak. Zoolang Van de Spiegel als gematigd democraat en voorstander van het Vorstenhuis der Oranje's er zijn machtigen invloed kon laten gelden, bleef de bestaande orde van zaken gehandhaafd, dank zij zijn verstandige maatregelen, om alle geweld in de kiem te smoren. Deze handelwijze bevorderde ook zijn candidatuur voor het ambt van raadpensionaris in Holland, waartoe hij als de geschiktste persoon voor dit hoogste ambt in den Staat in 1787 werd benoemd. Toen hij dit ambt op het einde van genoemd jaar had aanvaard, trachtte hij ook in Holland de partijtwisten op den achtergrond te dringen en met wijze gematigdheid het algemeen belang voor te staan. Hoewel de politieke hartstochten telkens te hevig werden opgezweept, om dat goede voorbeeld algemeen navolging te doen vinden, bereikte hij toch in de periode 1787-'95, dat de staatsregeling voorloopig gehandhaafd bleef, de buiten- 
landsche politiek van ons land werd gerugsteund door het defensief verbond van ons land met Engeland en Pruisen, vooral het werk van den raadpensionaris, dat de financiën der koloniën werden verbeterd, dat veel misbruiken in bestuur en financiewezen werden weggenomen, doch de bij herhaling fel oplaaiende partijschappen en de baatzucht van vele onderdanen, de stroef werkende staatsmachine en tal van vooroordeelen beletten te dikwijls, dat van zijn wijze bestuursmaatregelen ten volle profijt kon worden getrokken. Zijn pacifistische idealen, zijn memorie ter gelegenheid van het congres van Pilnitz in 1791, een waar meesterstuk van staatsmansbeleid en staatkundige omzichtigheid, alsmede zijn algemeen beleid in een der hachelijkste tijdsgewrichten van ons nationaal bestaan hebben overtuigend bewezen, welk een groot staatsman Van de Spiegel is geweest. Niet enkel intellectueel, vooral ook moreel. Man van plichtsbesef, die ontzettend veel van zich zelf eischte, wien geen inspanning of arbeid in 's lands belang te veel was, die niet zag op de uitkomst van, veel minder op loon voor den arbeid doch op de waarde van dien, die steeds zijn veelzijdige kennis en groote gaven van hoofd en hart besteedde voor het algemeen welzijn doch niettemin met grievenden ondank werd beloond, wien zelfs het recht om zich te verantwoorden en te verdedigen werd geweigerd, aldus kan in 't kort de karakteristiek van zijn ambtsvervulling als Hollands raadpensionaris worden samengevat.

Want toen de brand der Fransche revolutie ook naar ons land dreigde over te slaan, de Fransche republikeinen ons land en staatshoofd den oorlog verklaarden, was het weer Van de Spiegel, die het groote gevaar het eerst en het meest trachtte te bezweren. Deze ramp werd a.h.w. voor hem aanleiding om zijn energie en staatkunde nog wijder te ontplooien en met het steeds hachelijker worden van de omstandigheden werden zijn vele en groote diensten, den lande bewezen, van des te meer waarde, doch eveneens door de meesten miskend, die hun heil van Frankrijk verwachtten. En toen de Franschen in 1795 over de bevroren rivieren ons land binnendrongen, bleef weer Van de Spiegel op zijn post, ofschoon hij door bemiddeling der Engelsche ambassade een schip had kunnen krijgen om evenals de familie van den Stadhouder met de zijnen uit het land te wijken. Doch hij weigerde, als zijnde dit een vlucht, den verantwoordelijken staatsman onwaardig; hij gevoelde zich bovendien sterk, gerust, onschuldig en onafhankelijk in de overtuiging zijn plicht te hebben gedaan. Hoe werd echter ook hij ontnuchterd en in zijn idealisme smartelijk getrof- 
fen, doordat het nieuwe Franschgezinde bestuur hem niet alleen van al zijn waardigheden ontzette, doch tevens zijn papieren en bescheiden verzegelde, hem persoonlijk, onder verdenking van politieke misdaden, in verzekerde bewaring stelde, hem als een berucht bandiet behandelde en elke gelegenheid tot verdediging en verantwoording ontzegde ${ }^{1}$ ). Maanden aaneen zat hij onschuldig in voorarrest in Den Haag, daarna nog drie jaren als gevangene, wiens zaak ter afdoening maar steeds werd uitgesteld, in het slot te Woerden. Met edele gelatenheid en Christelijke berusting droeg hij dit zoo zware en onverdiende leed, slechts getroost door de aanwezigheid van zijn trouwe echtgenoote en hun jongste kinderen, die als eenmaal de familie van Hugo de Groot in het slot Loevestein de wangunst der tijden deelden met hun door het lot gebroken man en vader. Wel zette hij ook hier onverpoosd zijn letterkundige studiën voort, doch toen hij en de zijnen eindelijk op het einde van 1798 den kerker mochten verlaten, wist Van de Spiegel al, dat zijn dagen spoedig gesteld zouden zijn. Zijn gezondheid had veel geleden door de beproevingen der laatste jaren, geestelijk was hij afgemat en hij bezat weinig weerstandsvermogen meer.

Eerst vestigde hij zich te IJselstein, doch toen er met den inval der Russen en Engelschen op Nederlandsch gebied in den zomer van 1799 opnieuw gevaar voor zijn persoonlijke veiligheid dreigde, en men van Den Haag uit werkelijk voornemens was hem wederom heimelijk gevangen te zetten, besloot hij deze kans niet af te wachten en zich bij den erfprins van Oranje (den lateren koning Willem I) te voegen, die zich toen te Lingen op Duitsch grondgebied ophield. Daar hield Van de Spiegel zich weldra onledig met de opstelling en het ontwerp van een nieuwe staatsregeling, naar het model van de historische Unie van Utrecht, doch ontdaan van haar fouten en gebreken. Dit is zijn laatste openbare en politieke werkzaamheid geweest, want kort nadat zijn vrouw en dochter zich te Lingen bij hem hadden gevoegd te zijner verpleging, werd hij door een nieuwen aanval van beroerte dermate getroffen, dat bij 7 Mei van het jaar 1800 nog vrij onverwacht overleed. In Lingen rustte sindsdien het gebeente van den eersten Minister van Zeeland en van Holland, voor wiens begrafenis en aandenken in den vreemde Scipio's woorden schenen

1) Zie mijn historisch feuilleton over deze smadelijke bejegening van den raadpensionaris in de Nieuwe Rotterdamsche Courant, 19 Januari 1937. 
geschreven, als het meest op hem van toepassing zijnde grafschrift: Ingrata Patria, neque ossa mea habebis."

Wanneer wij na deze korte biografie ons nu de vraag stellen, welke beteekenis heeft, speciaal voor West-Indië en zijn verleden, het optreden van den raadpensionaris Van de Spiegel gehad, dan is het antwoord daarop niet zoo maar in enkele woorden samen te vatten.

Als men Van de Spiegel's "mondelijke verklaringen in den kerker" nog eens doorleest als - volgens opgave van den patriot Prof. Johan Valckenaer, de fiscaal in het proces van den afgezetten raadpensionaris - de "particulariteiten door Van de Spiegel aan mij (J. V.) verhaald op den avond van 2 December (1795) op de Voorpoorte" (te 's Gravenhage), dan vallen in verband met zijn bemoeiingen ten aanzien der koloniën vooral deze herinneringen op, uit zijn memorie zoo opgeschreven, als hier volgt:

„Gevraagd wat hij (Van de Spiegel) dacht over de ordres door den Prins uit Kew afgevaardigd naar onze Colonien? antwoordt hij: ,dat die hem dat geraden had, hem een zeer slechten raad had gegeven.

„De Pruisische historie aan hunne leveranciers heeft 5 à 6 millioen gekost. Praesenten behalve de gouden medaille aan Brunswijk zijn aan niemand gegeven: ik zweer daarop en passeere condemnatie van mijn hoofd.

25 millioen aan de O.I. Comp.

Eenige sommen aan de West .

Vele aan de bijzondere steden. Ziedaar het emplooy, dat nooit door mijne handen is gegaan, maar tot een stuiver toe op de Financiën van Holland moet gevonden worden.

De West-Indische Coloniale Raad heeft mij zeer veel moeite gekost; dat men Suriname en de Berbice er bijgevoegd heeft, is zeer goed, maar men heeft het stuk zelve gerenverseerd. Bij mijn tijd was er 7 tonnen gouds producten meer (nisi fallor) dan bevorens in 't Vaderland geimporteerd.

Ik had gaarne de O.I. Compagnie behandeld als de West, maar ik kreeg zooveel handen op mijn hoofd, dat ik dit moest laten varen. Zoo ik mij desaangaande gedurende mijn Ministerie iets reprocheer, is het het gestadig secours in geld; dat Ligchaam is niet te redden; men moest het hebben laten springen en de Compagnie reduceren, tot de vaart op de producerende en agricolerende landen, Ceylon, de Kaap en de Molukkes. Voor de rest de vaart openzetten". 
Deze „memorieposten” uit het regeeringsverslag van den raadpensionaris, door hem in zijn gevangenis op deze sobere wijze verantwoord, bewijzen duidelijk, hoezeer de koloniale belangen van zijn land steeds nauwlettend door hem waren behartigd. Door den steeds meer verslechterden toestand der koloniën, den desolaten staat der W.I. Compagnie en den achteruitgang van den Westindischen handel had hij ten slotte gepoogd, om nog te redden wat er te redden viel met het bekende resultaat. Geen handelslichaam met politieke strevingen en belangen had van de slechte uitkomst van den vierden Engelschen oorlog in die mate geleden als genoemde Compagnie en haar weerstandsvermogen na een lange lijdensperiode was nu geheel uitgeput. Twee maatschappijen, die achtereenvolgens bij octrooi het monopolie hadden gekregen om handel te drijven en zeevaart te ondernemen op de Westindische eilanden en de kusten van Amerika en Afrika, hadden allengs haar rechten moeten prijsgeven, haar invloed zien slinken, haar autoriteit verloren en haar kapitaal als sneeuw voor de zon zien verdwijnen. Wat was er in de tweede helft der 18de eeuw, toen Van de Spiegel zich haar lot moest aantrekken, van het staatsmonopolie overgebleven? Nergens vindt men dat juister en kernachtiger uitgedrukt dan bij Dr. A. J. van der Meulen in diens proefschrift „Studies over het Ministerie van Van de Spiegel" (Leiden 1905), die daarvoor het eerst gebruik maakte van Aristodemus en Sincerus' Brieven over het Bestuur der Coloniën Essequebo en Demerary (A'dam, 1785-'88, 12 dln.), een hoogste waardevolle bron, ook voor andere onderzoekingen betreffende de Westindische geschiedenis van dit tijdperk. Het meest karakteristiek is daaruit wel deze beschouwing:

„De vaart op de West-Indien was opengesteld tegen recognitie- en lastgelden voor alle Nederlanders; de Compagnie had daarentegen hare verplichtingen behouden. Zij beheerde onder souvereiniteit van H.H.M. de West-Indische bezittingen, bezorgde justitie, politie en religie, zelfs was zij met de verdediging belast. Een voordeelige zaak was de Compagnie onder zulke omstandigheden niet; zij ging meer en meer achteruit en schoof zich ongemerkt met het nog gereserveerde recht van slavenhandel weldra ook de verplichting om de koloniën van de noodige slaven en provisiën te voorzien van den hals. Ook de slavenhandel werd dus opengesteld voor Nederlandsche schepen. Toen de Compagnie zich daarvan ontlast had, vermoedde zij niet van welke vèrstrekkende gevolgen dat zou worden. Immers de landbouwende koloniën waren toen nog in haar opkomst, de Compagnie zag er 
niet naar om. Omtrent het midden der 18de eeuw begonnen zij evenwel meer de aandacht te trekken; Essequebo en Demerary, vooral het laatste, namen een ongekende vlucht. Met den steun van Hollandsch en Zeeuwsch kapitaal werden uitgestrekte gronden in cultuur gebracht; de hoeveelheid suiker, cacao, katoen en koffie door deze jonge koloniën te Middelburg aan de markt gebracht, werd zeer aanzienlijk. Voor de verloopen West-Indische Compagnie waren zij een prachtige aanwinst: met begeerigheid vielen Bewindhebbers op de kolonisten aan om op hunne kosten de vervallen Compagnie wat op te halen. Ongelukkig voor de handelsmaatschappij was haar octrooi niet berekend op het beheer van plantagekoloniën met blanke planters. De planters waren voor een groot deel van Nederlandschen stam, van nature weinig aan tucht gewend en allerminst gediend van een maatschappij, wier doel het was winst te maken. Het duurde niet lang, of zij hadden gezorgd voor een vertegenwoordiging hunner belangen in den Kolonieraad, waarin zij zich niet altijd even lijdzaam betoonden tegenover de dikwijls despotieke maar bijna altijd taktlooze orders van Heeren X. Heeren X waren slechte meesters voor de planters. Terwijl zij de belangen van hun Compagnie altijd voor oogen hadden, werden die der planters schromelijk verwaarloosd; geen order werd uitgevaardigd, geen maatregel genomen of op de een of andere wijze ondervonden de kolonisten er nadeel van. In de eerste plaats hadden deze te lijden van den onderlingen naijver van Holland en Zeeland. Op niet geheel regelmatige wijze waren Essequebo en Demerary onder beheer der Compagnie gekomen ${ }^{1}$ ). Toen de koloniën voordeelen begonnen te beloven, had Zeeland zijn uitsluitend recht daarop willen handhaven, terwijl de Kamer van X zich de vette bout niet wilde zien ontgaan. Het geschil was reeds Willem IV ter beslechting opgedragen; Willem V deed eerst in 1770 uitspraak. Tot dien tijd had Zeeland uitsluitend de vaart op de koloniën gehad en aan die koloniën geleverd, alleen de prijzen van de aangebrachte goederen op de markt van Middelburg bepaald, alleen de prijzen van de aan de koloniën geleverde goederen naar de Middelburgsche markt vastgesteld, alleen de vrachten aangeboden, alleen dus de prijsbepaling ook daarvan in handen gehad. Geen wonder dus dat Zeeland niet gaarne zijn rechten aan de Kamer van $\mathrm{X}$

$\left.{ }^{1}\right)$ Behalve de door Dr. v. d. Meulen genoemde bron: Verslag OudArchief Middelburg 1898 kan hier ook nog verwezen worden naar Netscher, Gesch. van Essequebo, Demerary en Berbice, 1888 en Rodway, Hist. of British Guiana, Georgetown, 1891-94. 
afstond. In 1770 werd het uitsluitend recht van Zeeland door de arbitrale uitspraak van den Prins vernietigd. De vaart op deze koloniën werd nu voor alle Nederlanders opengesteld, doch slechts in naam daar de uitspraak tevens den Zeeuwen een concessie deed, waardoor inderdaad het voorrecht van uitsluitende vaart werd gehandhaafd. In 1772 werden de termen nog veranderd in dien geest, dat gedurende de eerste zes maanden van het jaar door de Zeeuwsche Kamer en de volgende zes maanden door alle Kamers gelijkelijk paspoorten voor Essequebo en Demerary konden worden uitgegeven. De Zeeuwsche Kamer behield daardoor een belangrijken voorsprong, omdat met voordeel alleen maar schepen voor de vaart op West-Indië konden worden uitgerust, wanneer de vaart onafgebroken kon plaats vinden. Desondanks nam evenwel de Hollandsche vaart op Essequebo en Demerary van jaar tot jaar toe; de Zeeuwen kregen concurrentie, zagen hun groote voordeelen verdwijnen. Toch bleven de voorrechten belangrijk genoeg; Zeeland kon door deze schikking nog altijd gemakkelijk concurreeren tegen Holland. Het totaal getal van naar Zeeland uitgeklaarde schepen was van 1771-1785 dan ook aanzienlijk grooter dan dat der voor de Hollandsche steden bestemde. En al was de meerdere vrijheid in de vaart den planters mede ten goede gekomen, toch bleven deze nog zuchten onder de nawerking van den vroegeren toestand, onder den druk van Zeeuwsche handelshuizen".

Het was echter niet alleen de concurrentie-zucht tusschen Zeeland en de andere belanghebbende gewesten, welke remmend werkte op de welvaart der kolonisten van Demerary en Essequebo. Het gebrek aan crediet en de stagnatie in de slaventransporten als gevolg van bedoeld credietgebrek veroorzaakten, dat er een levendige smokkelhandel ontstond met de Amerikaansche vrijbuiters, waardoor moederland en Compagnie ten zeerste werden benadeeld. Ook met die transporten van gekochte arbeidskrachten aan de kusten van Guinea, waar de slaven voor de Westindische bezittingen moesten gehaald worden, werd dusdanig geknoeid, dat de slaven ten slotte onbetaalbaar waren en de koloniën verliepen wegens gebrek aan werkkrachten, verschillende plantages in Essequebo en Berbice niet meer bebouwd konden worden en verlaten werden. De Amerikanen smokkelden nu in ruil voor suiker, melasse en rum slaven naar de gebieden, hetgeen door de maatregelen van een verouderde handelspolitiek niet langer kon worden belet. Ook de aangevoerde producten uit de Nederlanden waren veel te hoog geprijsd, soms $50 \%$ en meer 
boven de waarde, zoodat de kolonisten zich van hout, meel en zout veel voordeeliger van Amerika uit konden laten bedienen, terwijl de door hen uitgevoerde producten koffie, suiker, katoen, rum, melasse enz. op de overvoerde markt in Nederland lage prijzen opbrachten. De kolonisten kochten - of liever ruilden, want specie in goud en zilver ontbrak, zoodat de handel met Amerika ook geen andere dan ruilhandel kon zijn -, tegen hun waren liever Amerikaansche visch en tabak, muilezels en paarden dan Hollandsche haring, die onderweg toch maar bedierf, en Amersfoortsche tabak, te slecht om gerookt te worden. Door den invoer van goud en zilver in specie als ruilmateriaal hadden de Bewindhebbers in elk geval den voor hen zoo nadeeligen ruilhandel in natuurproducten sterk kunnen beperken, doch zij deden ook in die richting niets. Vooral den katoenhandel, toen in opkomst, trok Engeland naar zich toe, dat wel goud of negers verschafte in ruil voor dit toen zeer gevraagde product van Essequebo en Demerary, voor welker vervoer de Nederlandsche schepen trouwens niet deugden. De hooge hypotheekrenten ten voordeele der Middelburgsche handelshuizen, waarmee de meeste plantages waren bezwaard, die op haar beurt weer betaald moesten worden met veel te laag getaxeerde producten van den bodem, veroorzaakten echter, dat ondanks den zeer winstgevenden smokkelhandel de economische toestanden der landbouwkoloniën van West-Indië verre van rooskleurig waren.

Dus kwam er een steeds meer groeiend verzet tot uiting onder de blanke kolonisten, die een beperkte vertegenwoordiging vonden in de Kolonieraden, terwijl de Bewindhebbers van hun kant niet minder ontevreden waren over het ongunstig verloop der zaken. Blijkens de Brieven van Aristodemus-Sincerus waren de lasten, die op het landbouwbedrijf in deze koloniën drukten, dan ook langzamerahnd zoo zwaar geworden, dat ze niet meer konden worden opgebracht zonder de geheele cultuur te vernietigen: hoofdgelden voor blanken en voor negers, akkergelden, productiegeld, uit- en invoerbelastingen, de laatste o.m. op paarden en rijtuigen, lasten op pluimvee, accijnsen, zegelrechten, veilgelden, huishuren, opcenten van de opbrengsten der plantages en der inkomsten van andere bedrijven, enz. enz. De klachten daarover bij de regeering des lands hadden vóór den vierden Engelschen oorlog bijkans geen andere uitwerking dan dat Zeeland met de andere provinciën in haar rechten op de koloniën werd erkend, waarvan Van de Spiegel dan ook het hiervoor gemelde besluit van den Prins van Oranje stadhouder Willem V, onder zijn bescheiden heeft opgenomen en van hetwelk de tekst als volgt luidt:

West-Indische Gids XIX 


\section{NADERE POINTEN RAKENDE DE VAART EN HANDEL OP DE COLONIE ESSEQUEBO EN DEMERARY DOOR ZYNE HOOGHEID BY ALTERATIE VAN HOOGSTDESZELFS REGLEMENT OP HET VOORSZ. SUBJECT IN DATO DEN 5 DECEMBER 1770 PROVISIONEELYK BERAAMD EN VASTGESTELD}

\section{1.}

Dat de Actens van Permissie of Pasporten tot de Vaart en Handel op de gemelde Colonie jaarlyks, gedurende de zes eerste Maanden van ieder jaar, by de Bewindhebberen van de West-Indische Compagnie, ter Kamer van Zeeland, alleen en privativelyk verleend en uitgegeven zullen worden, en dat daar en tegen, gedurende de zes laatste Maanden van ieder jaar de voorsz. Actens of Pasporten zo by de Bewindhebberen ter Kamer van Zeeland voornoemd, als by de Bewindhebbers van alle de andere Kamers van de West-Indische Compagnie, aan allen, en een iegelyk, der Ingezetenen onder hun Ressort geaccordeerd en geëxpedieerd zullen worden.

2.

Dat het aan de Schepen van de Commerciërende Onderdanen van den Staat, buiten de Provincie te huis horende, insgelyks vry zal staan om in de zes eerste Maanden van het Jaar op de voorsz. Colonie te mogen Navigeren, mits voorzien wezende met Pasporten of Hout- en Zout Brieven, by de Bewindhebberen ter Kamer van Zeeland afgegaan, en hunne Navigatie naar en uit de Colonie transitoir over de laatstgemelde Provincie dirigerende, op den voet, en in conformiteit van het gestatueerde by het 2 . Articul van het bovengemelde Reglement.

3.

Dat met opzigt tot het innemen van de Retouren, en de terugreize der Schepen, deze regul zal moeten worden geobserveerd, dat de Schepen met Pasporten, of Hout- en Zout-Brieven van Bewindhebberen ter Kamer van Zeeland voorzien, eerst en voor alle andere tot het laden en innemen hunner Retouren geadmitteerd zullen moeten worden, met dien verstande nochtans, dat deze praeferentie zig niet verder als tot een bepaald getal van negen Schepen s'Jaarlyks zal uitstrekken, en voorts onder deze bepaling, dat van die praeferentie alleen zullen jouïsseren zodanige Schepen, op Pasporten of Hout- en Zout-Brieven van de Kamer van Zeeland Navigerende, welke voor het uiteinde van de Maand November van ieder Jaar in de Colonie zullen wezen aangeland, en dat overzulks, zo wanneer het voorzeide getal van zoodanige Schepen, op de Expiratie van den bovengemelden tyd in de Colonie bevonden mogt worden te deficiëren, alle de verdere Schepen, buiten de Provincie van Zeeland t'huis hoorende, en op de Pasporten van eenige der andere Kameren van de West-Indische Compagnie dezer Landen uitgegeven, immediaat daar op tot het laden, en innemen hunner Retouren toegelaten zullen worden. 
Dat laatstelyk de Schepen, welke in de laatste Maanden van het Jaar uit deze Landen naar de voorsz. Colonie vertrekkende, niet eerder als in het volgende Jaar aanlanden, hunne Retouren niet zullen mogen innemen, voor en aleer alle Schepen, gedurende het vorige Jaar in de Colonie gearriveerd, volladen zullen zyn.

Wordende hier mede, en door het gunt voorschreven is, de Dispositie van het bovengemelde Reglement, voor zoo veel het zelve met de teneur dezer nadere Articulen is contrariëerende, mitsdezen gehouden voor gealtereerd en gederogeerd.

Gedaan in 's Gravenhage den 15. January 1772.

(Getekend) W. Pr. v. Orange"' ${ }^{1}$ ).

Prof. G. W. Vreede verwees in een aanteekening bij dit stuk in 1874 reeds naar „Verg. aangaande Volkplanting NOVA ZELANDIA aan de rivier Essequebo, en over de langwijlige twisten der belanghebbende Kamers, het verhaal en de Bijlagen tot L UZ A C, HOLLANDS RIJKDOM II, 141 volg. 244 volgg. 255 en wijders in het Aanhangsel, de Staatstukken van $1750,1751,1769$, 1770-1772, bl. 188-247." Maar in niet mindere mate geldt die beteekenis als bron de reeds aangehaalde „Brieven over het Bestuur der Coloniën Essequebo en Demerary, gewisseld tusschen de Heeren Aristodemus en Sincerus, nevens bijlagen tot deze briefwisseling en eene voorreden van den Nederlandschen Uitgeever (Te Amsterdam bij W. Holtrop, 1785-1788 in 12 dln.)" en de hier nog niet eerder genoemde periodieken, naamloos uitgegeven onder den titel van „De Oost- en West-Indische Post, behelzende: consideratiën over de critique toestand der coloniën. Met Aanhangsel De Extra Oost- en West-Indische Post, En met Vervolg: De Oost- en West-Indische Post, behelzende: Den tegenwoordigen Staat en de middelen van herstel van de O.I. Comp. in Nederland." I-II daarvan zijn verschenen in de jaren 1784-'85 bij J. M. van Vloten en J. J. Besseling te Utrecht, terwijl nog een derde deeltje uitkwam bij J. Verlem. Het zijn in gematigd democratischen en Patriottischen geest gestelde klachten en verweerschriften in den toen zoo gangbaren briefvorm, waarmee vooral de kolonisten gelegenheid vonden om hun grieven tegen het vaak averechtsche bestuur der Bewindhebbers tot uiting te brengen. De redacteur maakte zich om die reden dan ook niet bekend evenmin als hij toeliet, dat zijn medewerkers hun namen onder de opgenomen epistels plaatsten. Met het derde deel werd echter de uitgave gestaakt, want de klachten en grieven „werden toch niet onderzocht" en de meeste ontoelaatbare toestanden „bleven

$\left.{ }^{1}\right)$ Luzac's Hollands Rijkdom, Leiden, 1780-83. 
gelijk ze waren." Beide bronnen vullen elkander heel goed aan.

Vooral toen door en na den Engelschen oorlog de toestand der kolonisten eer beter dan slechter was geworden. Ook nadat de Franschen deze koloniën hadden heroverd, werd er meer voor de inwoners gedaan dan te voren: wegenaanleg, waarover de Bewindhebbers zich nimmer hadden bekreund! Maar na den vrede trad spoedig de oude toestand van het laisser faire weer in en stak de reactie driester dan ooit het hoofd weer op. Vergoeding voor de geleden schade tijdens den oorlog: de vruchten van twee jaren arbeid der kolonisten om in de kosten der verdediging bij te dragen, bederf van sommige producten, welke niet vervoerd konden worden, oorlogsschade ter zee, daaraan werd niet gedacht, maar bovendien trachtten de Bewindhebbers den invloed van den Kolonialen raad dermate te breidelen, dat de planters bijkans uitgesloten werden om in politiek en economisch opzicht eenigen invloed te doen gelden. Want de nieuwe Raad zou voortaan samengesteld zijn uit Compagniesdienaren en kolonisten, wier eed inhield, dat zij van alle zelfstandigheid ten aanzien van te nemen besluiten afstand moesten doen. Gevolg was dan ook, dat de planters zulk een lichaam niet wilden erkennen, waardoor eigenlijk een toestand van anarchie intrad. Noch de DirecteurGeneraal, noch de Heeren X noch zelfs de Souverein, de Erfstadhouder, bleken van zins daarin verbetering te brengen en zoo kon het geschieden, dat de „Kamer” of Kolonieraad van Essequebo en Demerary een college werd, waar coöptatie bij de verkiezing van nieuwe leden regel werd en zulke nieuwe leden ten slotte niet eens meer werden gekozen of gecoöpteerd, wanneer de ambtenaren der Compagnie werden ontslagen, stierven of om andere redenen uit hun dienstverband traden. De planters hielden intusschen niet op hun ongenoegen en ergernis over dien toestand te doen weten aan elk, die maar naar hun klachten en grieven luisteren wilde, totdat de vergadering van Heeren X zich incompetent verklaarde, hierin verbetering te brengen en de Souverein zoowel als Heeren Hoogmogenden zich zeer ontstemd toonden over den „boozen, opgewonden” toon der verongelijkte planters en verdere kolonisten. Ook uit "particuliere brieven”, sedert 1784 gericht aan de bovenaangehaalde „Oost- en West-Indische Post" blijkt nog duidelijker, hoe de situatie in de landbouwende kolonies Essequebo en Demerary was. Daarom volgt hier de tekst van een der stukken, dien men vindt in 


\author{
„DE OOST- E N W E S T-I N D I S C H E P O S T. \\ Extra No. 29. \\ $\mathrm{O} \mathrm{F}$
}

\author{
A A N H A N G Z E L \\ Tot de ordinaire Nommers.
EXTRACT UIT EEN PARTICULIEREN BRIEF, ONTVANGEN VAN DEMERARIJ, 1784".

Het is dan zeeker dat men, in het Vaderland, overtuijgd is, dat de Administratie der Justitie, zelv na het ingevoerde Nieuwe Reglement, op de zelve, van den Jaare 1772, alhier niet zo overeenkomstig aan dat Nieuwe Reglement, nog aan de intentie en de volkoome noodzakelijkheid, is uijtgevoerd geworden; en dat, uit dien hoofde, volgens alle Berichten, men aldaar, ter geleegendheid van de Institutie deezer Colonie aan de Republicq, onder andere Poincten van Redres, insgelijks dit, als een der Hoofd-Poincten, in serieuse overweeging heeft genoomen; en daar aan zal trachten te subvenieeren; zo is het, dat ik het van mijnen indispensabelen plicht geoordeelt hebbe, UE., bij deezen het een en ander, tot dit stuk betrekkelijk, onder 't oog te brengen; als oordeelende van de uiterste noodzakelijkheid, EN HET ALLERGROOTSTE BELANG IN 'T ALGEMEEN, VOOR DE GEINTRESSEERDEN IN DEEZE VOLK-PLANTING, EN IN 'T BIJZONDER DIENVOLGENS OOK VOOR UE., als het belang der gezamenlijke belanghebbenden in de Negotiatie waarneemende.

Het schijnt, in 't algemeen, dat men, in 't Vaderland, genoegzaam overtuijgd is, dat de Ingezeetenen deezer Colonie merkelijk geleeden hebben bij deezen Oorlog; zo door het neemen; als herneemen, en de gevolgen van dien. Het zal dienvolgens onnoodig zijn, het zelve alhier in 't breede te detailleeren, en ik zal alleenig de Vrijheid neemen, UE. te doen aanmerken, dat, hoe zeer de verliezen, door het neemen van zo veele rijke Scheepen met producten, van hier gelaaden, en alle, door 't manqueeren der assurantie-ordres, in tijden, door de Planters en Eijgenaars geleeden, important zijn geweest, dezelve echter alle nog een gering gedeelte uitmaken, van 't geen de Colonie, in het algemeen, door den Oorlog heeft uitgestaan. Duurte van Levensmiddelen, enorme hooge assurantiën, ten tijde der Engelschen, schaarsheijd van, ja volkomen manquement aan geleegenheeden, om producten, die alhier daar door zijn moeten bederven, afte scheepen, gedurende een zeer geruijmen tijd, na de herneeming door de Franschen, om niet te zeggen gedurende bijna dien gantsche tijd, enorme hooge vragten en dan, 't geen nog 't allertreffendste is geweest, laage prijzen der producten in ' $t$ algemeen, en bijzonder der Suijkers, doe dezelve eindelijk in Europa ter markt zijn gekoomen, zijn de gevolgen geweest, welke de Hoofdslagen en de groote verliezen hebben veroorzaakt voor deeze Colonie voor de Planters en Eijgenaars der Plantagien direct, maar even zo zeer, schoon indirect, voor de geldschieters, en zelv, voor alle de Ingezeetenen van 't Vaderland, door de gevolgen van die verliezen der Planters, en Eygenaars van Plantagien; men zwijge van andere gevolgen van het Oorlog, ofschoon de schaarsheijd, ja men mag zeggen, het geheel cesseeren, van aanvoering van Neegers (eene weijnige, en dat 
voor aller exorbitantse prijzen uijtgezonderd) insgelijks gecontribueerd heeft, in eene groote maate, tot enorme schaade voor deeze Colonie; en hoe zeer dat de verliezen, en schaaden, uit al dit opgenoemde, minder in 't oog loopen, dan wel de verliezen, door 't neemen der gelaade producten, zo zijn dezelve echter niet minder, maar zelfs veel importanter, alware het maar, dat dezelve veel algemeener, en volstrekt door een ieder, en generaal geleeden zijn, en van twee zijden hebben gewerkt; te weeten meerder en hooger uitgaaven voor noodwendigheeden, en minder en geringer ontfangst van inkoomen.

Dat nu deeze verliezen, betrekkelijk tot de faculteiten van de meeste Planters in 't algemeen, zo groot geweest zijn, dat die niet in staat zullen zijn, te kunnen voldoen aan alle hunne engagementen, lang voor den Oorlog gemaakt, en betrekkelijk tot de Geldschieters, schijnt in ' $t$ algemeen ook genoegzaam in Holland in aanmerking genoomen te worden, en in 't bijzonder door UE. blijkens de Missiven reeds voorleede Jaar van Heeren Directeuren aan mij, daar omtrent, schoon in algemeene bewoordingen, geschreeven ${ }^{1}$ ).

Dan het is ook bij mij ontwijffelbaar, alzoo men, onder alle Classes van menschen, er vind van verschillenden imborst, redeneering, denkens, en handelwijze, dat de zwaare verliezen, de gewoonte zeedert 3 Jaaren door noodzakelijkheid ingevoerd, om alles in producten te betaalen, en dat in het algemeen (naar mijn oordeel) tot wel hooger prijzen, dan dezelve, alle door een geslaagen, bij verzending, na Europa, voor eige reekening gerendeerd zouden hebben, het lage Netto provenue der producten voorleeden Jaar na Holland verzonden, de ongewoonte van intresten der genegotieerde penningen te betalen, en meer andere bijkomende oorzaken, bij zommigen voor uijtvlugten, en voor redens van mogelijk grootere onmacht, dan in der daad existeert, zullen worden aangehaald; en daar door zelvs reedelijke, en aanneemlijke voorslagen van remissie, van een gedeelte der verschuldigde intresten, door sommigen zullen worden geresuseerd, of nog gedaane beloften, daar aan niet zal worden voldaan; het is dan het vooruitzigt van dit, mijne Heeren, het geen mij doet voorkoomen dat het aller importantste poinct voor een ider bij deeze Colonie, het zij direct of indirect in 't Vaderland geinteresseerd, thans in de bezorging van eene regulier: prompte en goede administratie van Justitie bestaat.

Het zij 'er echter verre van daan, dat ik aan Ue. zoude willen voordraagen, als of de geldopneemers in UEd. Negotiatie, hetzij alle, het zij zommige Derselver, zouden behoren tot de Classis van Leeden, die zig van uijtvluchten zouden bedienen, reedelijke, en aanneemelijke voorslaagen van Remissien, afslaan, of Profiteeren willen van de mindere goede en prompte administratie van Justitie; dit zoude, ten uitersten onregtvaardig, en in mij te blameeren zijn, zo lang ik door ondervinding daar geen grond toe had; het zoude vermeetel van mij, hoonende en beleedigend voor hun alleen en voor ijder hunner in ' $t$ bijzonder zijn, dan dewijl het beste is, volgens de bekende Lateijnse spreuken, SICH TOT DEN KRIJG GEREED TE MAKEN, WAN-

$\left.{ }^{1}\right)$ De anonieme schrijver blijkt dus man van eenige autoriteit en invloed te zijn geweest, die met het Compagniesbestuur in patria in nauwe relatie stond. 
NEER MEN DE VREEDE WIL BEHOUDEN, en dat somtijds reedelijke en aanneemelijke voorslagen zouden kunnen verworpen worden, niet uit kwaade grondbeginselen, maar om dat somtijds door verkeerde begrippen, en redeneeringen van sommige voor onreedelijk, en onaanneemelijk zoude worden aangezien, en dat zelfs een goede en prompte administratie van Justitie veele derzelven in staat zoude stellen, om te voldoen aan 't geen zij schuldig zijn, en verlangen te voldoen, door des te beeter te recouvreeren 't geen hun daar en teegens van andere, somwijlen minder weldenkende Debiteuren, verschuldigd is, so is het, dat ik, in dit tijdstip, heb geoordeeld, dat de bezorgen van eene prompte en goede administratie van Justitie, voor een ijder belanghebbende in deeze Colonie, meer dan ooit, hoognoodzakelijk en voor alle de geldschieters van het alleruiterste gewigt en belang is.

Het zoude overtollig, en te kort gedaan zijn aan UEd. verligt verstand, en aan dat van die geenen, aan wien de beschikking, omtrent de Administratie der Justitie alhier, voor 't vervolg, onder den souverain, toevertrouwd is, of toevertrouwd zal worden, om alhier in 't breede uit te leggen, den invloed van zodanige goede of kwaade administratie op de Bloeij Ja op de geheele Existentie eener maatschappij; dan, mijne Heeren! het is eene onwrikbaare waarheijd, dat geen verbeeldingskragt, geen beschouwing in Theorie, ooit op iemandt dien indruk kan maken, of aan dezelve zo Levendig kan voorstellen, de meenigte, ende aaneenschakeling van de nadeelige gevolgen zo voor den Bloeij en aanwasch van eene Maatschappij, in 't algemeen, als voor 't belang van ijder Lid derzelver, en van die daar bij, het zij direct of indirect belang hebben, dan dewelke de ondervinding maakt, niet van eene kwaade administratie van Justitie zelfs, maar eenvoudig van eene Justitie, welke niet, in allen deelen, regelmatig, en exact, na de ordre, door den wetgeever voorgeschreeven, word geadministreert, en geëxerceerd, en hoe veel meer dan, mijne Heeren! daarvoor, en bij een regtbank, van waar voor de Partijen de Revisie der sententien door hooger Rechters in 't Vaderland open is, zo verre van hier geleegen, en alwaar op de minste omissie, of afdwaling van de voorschreeve forme, volgens het recht en de wetten van den souverain, althans absolutie van de instantie moet werden verleend al waare anders de uijtspraak, in alle deelen, Conform alle Billijkheijd in de beschreeve rechten.

Dat de administratie der Justitie in deeze Colonie, zo wel voor, als na de opregting der Twee Hoven van Justitie, en het introduceeren van het nieuwe Reglement op dezelve, van den Jaare 1772 niet is gevoerd, en geëxerceerd geworden, Conform aan de Intentie, ofte aan de formen, volgens de Holls. wetten verëischt, blijkt ook allezints in het Vaderland bekend te zijn; ofschoon ik volstrekt moet geloven, jaa zelfs ten vollen overtuijgd, en verzeekerd ben, dat al het gebrekkige, al het Irreguliere daar van in geenen deelen, aldaar bekend is, ende althans op verre na niet genoegzaam bij die geene, aan wien het zal staan, en aan wien het zal toeberouwd zijn, of werden, omme daar efficasieus in te remedieeren, voor 't vervolg.

Dan zelf dit al eens toegestaan zijnde; zo blijft het grootste, het voornaamste, Point over, Het Poinct, mijne Heeren! daar alles van 
afhangt, het Poinct, daar de groeij, Bloeij en aanwasch van deeze Colonie, thans voornamelijk, moet uit voortspruijten, en daar dienvolgens so veel aangeleegen ligt, voor alle planters, eijgenaars en Ingezeetenen van deeze Colonie, voor alle geldschieters op Effecten in dezelve, voor s'Lands Ingezeetenen die in Europa, door Commercie, en navigatie, onmiddellijke, en voor alle die door de voordeelen, weer verder uit die Commercie, en navigatie voortvloeijende, minder onmiddellijke, maar even gelijke Indirecte Belangen daar bij hebben; ik meene het poinct om Efficatieuse schikkingen te maken, ten einde, in 't vervolg, beetere, en meer Reguliere administratie van Justitie te bekomen.

Niet, dat ik daar door zo zeer beooge, mijne Heeren! als ofte de teegenswoordige en voorleeden regtbanken, alhier onrechtvaardige en eenzijdige uitspraaken gedaan, ofte Justitie geweigerd hadden. Dit zij verre van mij van alhier ter neertestellen, dit is verre buijten mijn bereik en geheel en al aliëen van mijn Bestek, om te onderzoeken" ' ${ }^{1}$.

Blijkt uit dezen brief, die nog met zekere reserve is geschreven, om de Heeren X, voor wie het epistel blijkbaar was bestemd, zij het dan ook langs den omweg van ,goede vrienden", niet te zeer te vertoornen, hoe zeer het gebrek aan een goede rechtsbedeeling in de kolonie de grondslagen van een op het recht ingestelde samenleving ondermijnde, ook in economisch en politiek opzicht werd de toestand zoo precair, dat geen middel onbeproefd werd gelaten, om de berichten daarvan in het moederland te verspreiden. Was het al niet erg genoeg, dat Essequebo en Demerary in den Engelschen oorlog niet verdedigd konden worden, zoodat deze koloniën tot tweemaal toe door vreemde naties waren buitgemaakt? En bovendien verontrustten de Boschnegers en slaven hoe langer hoe meer de veiligheid der planters en verdere blanke kolonisten. Wat zou dit handvol blanken, bijkans zonder verdediging gelaten tegen buitenlandsche veroveraars zoowel als tegen binnenlandsche onruststokers, ten slotte ter zelfverdediging uitrichten tegen die negers en slaven, als de laatsten eens de handen in elkaar sloegen tot uitroeiïng hunner meesters en naburen? Sedert 1780 toch hadden er jaarlijks reeds negeropstanden plaats gehad en tegenover de ruim 30 duizend slaven van Essequebo en Demerary en de bijna 70 duizend, welke in de gezamenlijke landbouwende koloniën werkten, konden in de eerste beide slechts 200 Compagniessoldaten gesteld worden; in Suriname wel wat meer, doch in elk geval nog geen 500! Wat moest zoo'n legertje van bovendien slecht uitgeruste combattanten beginnen, als de opstand eens een algemeen en massaal karakter aannam? Want onder die in een uniform of monteering gestoken combattanten

1) O. en W.I. Post, II, 249-256. 
waren ook nog de invaliden, ouden van dagen en verminkten begrepen, en hun officieren hadden van legerleiding en bevelvoering niet het minste begrip. De fortificaties verkeerden in den meest deplorabelen toestand, het geschut, de ammunitie waren pro rata, zoodat het militair verweer van geen waarde kon heeten. En den kolonisten ontbraken door den slechten financieelen toestand de middelen, om hierin verbetering te brengen. De schuld daarvan werd in den volgenden particulieren brief echter niet geheel het Compagniesbestuur in patria aangewreven, want ook de planters in de kolonie gingen allerminst vrij uit.

„Nader EXTRACT uit een Brief van een Heer in DEMERARIJ aan zijn Vriend in AMSTERDAM, geschreven, IN 'T JAAR 1784 .

Ik kan niet zien dat eenige der Comptoiren zoo veel Intresten zullen uitdeelen, dat men de wezentlijke schadens door de Planters geleden, ras zal vergeten, zoo als UEd. zig schijnt te verbeelden, integendeel immers in deze Colonie, zijn de Planters veel meer vergeetende geworden, omtrent hun pligt en de verbanden, eertijds genomen: kwaade gebruiken maakt men zig ligt eijgen; zeedert drie Jaaren heeft men 't betalen van Intrest, het afzenden naar HOLLAND, weinig of niet gedaan, en men is het dus al vergeten: voeg hier bij, Dat de meeste ENGELSCHEN, welke hier zijn gekomen, na de verovering, der Colonie, volgens gewoonte veragten, wat andere natien doen, en bijzonder de gebruijken hunner aartsvijanden, de HOLLANDERS, alle Planters en bijzonder die van hun Natie d'ooren hebben volgeblazen, over de hardigheid der Hijpotheeken, en de onredelijkheid der Directeurs, en geldgeevers, aan welk weder veel meer, dan de waarheid wierd te last gelegt.

Na deeze Engelschen, koomen de FRANSCHEN, in wiens Eijlanden nog Hijpotheecq, nog arrest valide is, tegens, of op eenige Plantage of iets tot Plantagien behoorende, als zijn slaaven, Meubilen, Paarden, of andere Vee, gereetschappen etc. Deeze schreeuwden allen, bijzonder de opperhoofden, teegens de onmenschelijkheid der verbanden, door de Planters genomen (l'inhumanité des Engagements!) sommigen hebben wel getragt, met bezaadigheid, hun de weezentlijke gronden dier verbanden, en hunne Reedelijkheid, uijtteleggen, d'ongehouden feniteit en inschikkelijkheid aangetoond, welk deeze wreede Geldschieters (ces capitalistes implacables), omtrent de Planters gebruikten, 't hielp weinig - vooroordeelen worden zeldzaam door redeneeringen weggenoomen.

Voeg hier nu eens weeder verder bij, dat (om 't in korte woorden uit te drukken) hier nooit regt is gesprooken, nog in de oude, nog in de tegenswoordige Hollandsche tijden. Veel min in de Engelsche en Fransche tijd. Eindelijk; dat de possessie, geduurende eenige Jaaren, de Bezitter de onregtvaardigheid doet vergeeten, der wijze op welke daar is aangekomen" 1 ).

1) O. en W.I. Post, dl. II, 290. 
Maar eerst toen in 1787 - Maart - een officieel rapport over den staat van zaken betreffende de Westindische Compagnie was uitgebracht, zulks in verband met haar steeds dringender geworden subsidie - aanvragen en de tallooze links en rechts verspreide, geschreven en gedrukte klachten der kolonisten, de requesten om den slavenhandel op Essequebo en Demerary voor iedereen en onbeperkt open te stellen, de dringende vertoogen tot een vaartverbod voor vreemde schepen op de W.I. eilanden, bleek haar ware toestand en kon een doortastend man als onze Raadpensionaris Van de Spiegel ingrijpen. Wat hij tijdens zijn hooge ambt nog voor de West heeft willen doen en trachten te bereiken, wat hij in dit opzicht nog heeft kunnen doen, zal het slot van deze bijdrage aantoonen.

(Wordt vervolgd). 